\title{
INSTRUMENTS OF POLISH FOREIGN POLICY TOWARDS THE POST-YUGOSLAV STATES
}

\author{
by Renata Podgórzańska
}

\section{INTRODUCTION}

The realization of Polish foreign policy after 1989 was carried out in the dynamically changing international situation. Political transformation in Poland and the redefinition of its foreign policy was parallel to farreaching events occurring in Europe. These were brought about by political transformation in Central and Eastern Europe, that is the collapse of the Easter block, reunification of the German states, break-up of the USSR and the independence of former Soviet republics. ${ }^{1}$ However, Europe of the time not only witness events leading to the disintegration of the Cold-War order, but also was an arena of military conflicts in its Southern

1 See: A. Burakowski, A. Gubrynowicz, P. Dukielski, 1989 - Jesień Narodów, Warszawa 2009: W. Roszkowski, Transformacja systemowa na tle porównawczym, „Studia Polityczne” 2001, No. 12, pp. 19-31; J. Stańczyk, Środkowoeuropejska „Jesień Ludów” (na przełomie lat 80. i 90. XX w.), [in:] Przeobrażenia systemowe w państwach Europy Środkowej $i$ Wschodniej. Stan aktualny i perspektywy, Z. Trejnis (ed.), Siedlce 2004; J. Wojnicki, Trudna droga do demokracji. Europa Środkowo-Wschodnia po 1989 roku, Warszawa 2002. 
regions. ${ }^{2}$ The Balkan conflict triggered a change in the approach and strategy towards those regions, in particular of those states which had their political or economic interest located in that area. ${ }^{3}$ In case of Poland, the dissolution of the Socialist Federal Republic of Yugoslavia (SFRY) did not cause any major changes regarding the character and ways in which Polish foreign policy was realized. This was only natural, considering the fact that the Balkan region played a secondary role in Polish foreign policy after the year 1989.4 At the same time, this fact did not mean that Poland was not interested in how the situation in the Balkans was developing or that it was not apprehensive of its aftermath. The support of military actions to end the Balkan conflict was dictated by a sense of international solidar-

2 See: J. Kiwerska, Świat w latach 1989-2009. Wydarzenia - konflikty - procesy, Poznań 2009; M. Kuczyński, Krwawiaca Europa. Konflikty zbrojne i punkty zapalane w latach 1990-2000. Tło historyczne i stan obecny, Warszawa 2001; M. Tanty, Bałkany XX wieku, Warszawa 2003; M. Waldenberg, Rozbicie Jugosławii. Jugosłowiańskie lustro międzynarodowej polityki, Warszawa 2005; S. Wojciechowski, Integracji i dezintegracja Jugosławii na przełomie XX i XXI wieku, Poznań 2002; M.J. Zacharias, Komunizm - Federalizm Nacjonalizm. System władzy w Jugosławii 1943-1991. Powstanie - przekształcenia rozkład, Warszawa 2004; M. Waldenberg, Rozbicie Jugosławii. Jugosłowiańskie lustro międzynarodowej polityki, Warszawa 2005, pp. 86-100; B. Koszel, Mitteleuropa Rediviva? Europa Środkowo- i Południowo-Wschodnia w polityce Zjednoczonych Niemiec, Poznań 1999; S. Wojciechowski, Integracja i dezintegracja Jugosławii na przełomie XX i XXI wieku, Poznań 2002, pp. 161-217.

3 I. Pawlikowska, Koncepcje bezpieczeństwa państw Europy Środkowej po 1989 roku, Toruń 2006, s. 42-43; B. Koszel, Mitteleuropa Rediviva? Europa Środkowo- $i$ Południowo-Wschodnia w polityce Zjednoczonych Niemiec, Poznań 1999; S. Wojciechowski, Integracja i dezintegracja Jugosławii na przełomie XX i XXI wieku, Poznań 2002, pp. 161-217.

4 See: R. Kupiecki, K. Szczepanik, Polityka zagraniczna Polski 1918-1994, Warszawa 1995; R. Kuźniar, Polska polityka zagraniczna, [in:] Historia współczesnych stosunków międzynarodowych, J. Kukułka (ed.), Warszawa 1994; R. Kuźniar, K. Szczepanik, Polityka zagraniczna RP 1989-2002, Warszawa 2002; W. Malendowski, Nowe uwarunkowania i cele polityki zagranicznej Polski po 1989 roku, [in:] Polska i jej sąsiedzi w latach dziewięćdziesiątych. Polityczne i ekonomiczne aspekty współpracy i integracji, B. Łomiński, M. Stolarczyk (eds.), Katowice 1998; Polska polityka zagraniczna w procesie przemian po 1989 roku, A. Żukowski (ed.), Olsztyn 1999; R. Kuźniar, Droga do wolności. Polityka zagraniczna III Rzeczypospolitej, Warszawa 2008; R. Zięba, Główne kierunki polityki zagranicznej Polski po zimnej wojnie, Warszawa 2010; R. Zięba, Transformacja polskiej polityki zagranicznej, „Rocznik Nauk Politycznych” 2004, No. 7. 
ity, responsibility for Europe's security and the readiness to participate in solving problems Europe was facing. These goals corresponded to the objectives defined by Polish foreign policy after 1989, including provision of the country's security. Stability in the Balkans was treated by Poland as an element of regional (European) security, therefore all factors threatening this security were perceived as jeoparady for Poland's security.

However, the scope and forms of our involvement differed significantly from the involvement of other European states. Considering the shape and scope of Polish diplomacy's activities in this region, one can notice that they were twofold. One part reflected decisions taken by the international community, whereas the other part reflected independent policy decisions. However, it must be underscored that Poland did not lead an autonomic policy towards this region, neither did it create the international policy in the Balkans, but merely took part in activities enforced by the international community. In other words, activities which were an element of international policy were predominant and independent initiative was just marginal.

The efficiency of Polish foreign policy regarding the Balkan region was determined by the selection of instruments (measures) and methods of their implementation. ${ }^{5}$ The term "instruments of foreign policy" used herein denotes every possibility, institution or policy which is used to achieve certain foreign policy goals and which has indirect or direct fea-

5 The term "instrument" is often used interchangeably with the term "measure" as within one of political, economic or military measures, a few instruments can be used. One of the Polish academics specializing in foreign policy instruments is Roman Kuźniar, the author of: R. Kuźniar, Międzynarodowe stosunki polityczne, [in:] Stosunki międzynarodowe. Geneza, struktura, dynamika, ed. E. Haliżak, R. Kuźniar, Warszawa 2006, pp. 127-128. See also: E. Cziomer, L.W. Zyblikiewicz, Zarys współczesnych stosunków międzynarodowych, Warszawa 2005, pp. 138-140; T. Łoś-Nowak, Polityka zagraniczna, [in:] Współczesne stosunki międzynarodowe, T. Łoś-Nowak (ed.), Wrocław 2008, pp. 88-94; J. Nowiak, Czym jest polityka zagraniczna, [in:] Stosunki międzynarodowe, W. Malendowski, C. Mojsiewicz (eds.), Wrocław 1998, p. 87; J. Zając, Środki i metody oddziaływania USA $w$ bliskowschodnim procesie pokojowym (1991-2000), Warszawa 2005, s. 14; J.J. Wiatr, Zarys nauki o stosunkach międzynarodowych, Warszawa 2008, pp. 20-22. 
tures of internationality. ${ }^{6}$ The decision to select given instruments was conditioned by organizational and financial resources available at the time, the number and compatibility of foreign policy goals, the gradation of priorities and their urgency, the scale and character of threats that accompanied the goals' implementation, social support for the actions in course, conviction about one's power and about the possibilities to affect the international community. Moreover, also the resources and possibilities of other states, including the states in the Balkan region and those involved in ending the conflict and stabilizing the region, played a significant role. ${ }^{7}$ At every moment throughout the conflict, the instruments used by Polish diplomacy were subject to modifications depending on the current situation in the region and on the extent to which goals set by foreign diplomacy had been accomplished.

The list of measures of international influence, that is of foreign policy instruments, which a state has at its disposal is long and extensive. ${ }^{8}$ Specialist literature offers a number of classifications of foreign policy instruments. The most popular criterion belongs to the area of social welfare which they originate from. On that basis instruments of political, economic, military, social and normative nature are distinguished. ${ }^{9}$ The number and nature of instruments a state uses depend on, inter alia, its political, economic, military and cultural potential, position on the international arena and the state's role in the system of international relations. Simultaneously, these factors determine how the external environment

${ }^{6}$ R. Vukadinović, Międzynarodowe stosunki polityczne, Warszawa 1980, p. 321.

7 T. Łoś-Nowak, Polityka zagraniczna..., p. 88.

8 See: R. Kuźniar, Międzynarodowe..., p. 127; T. Łoś-Nowak, Polityka zagraniczna..., pp. 88-94; W. Szymborski, Międzynarodowe stosunki polityczne, Bydgoszcz 2008, pp. 231-232; J. Zając, Środki..., pp. 79-97; J. Winiecki, Ekonomiczne instrumenty polityki zagranicznej we współczesnych stosunkach międzynarodowych, Warszawa 1975, pp. $10-30$.

9 R. Kuźniar, Międzynarodowe..., p. 127. See: Z. J. Pietraś, Podstawy teorii stosunków międzynarodowych, Lublin 1986; T. Łoś-Nowak, Polityka zagraniczna..., p. 88-94; I. Rysińska, Środki i metody polityki zagranicznej, [in:] Polityka zagraniczna państwa, J. Kukułka, R. Zięba (eds.), Warszawa 1992, s. 77-96. 
can be influenced and also what is the chance that one's own interests and foreign policy goals will be accomplished. ${ }^{10}$

The selection of instruments of Poland's foreign policy towards the states in the Balkan region corresponded to the region's place and role in Polish foreign policy, to the priorities set and possibilities that Polish diplomacy had at hand. It should be underlined that Polish foreign policy regarding this region was closely linked to the policy's directions and goals that were realized, as well as to the events accompanying the dissolution of SFRY and efforts to reestablish peace and stability undertaken by the international community. At the same time, the form of Poland's involvement and the instruments used were conditioned by the policy led by the Balkan states, intentions that accompanied their actions and their ability to absorb external support. Nevertheless, the selection of instruments was as much decided by the resources available to Poland at the time. Each phase of the policy implementation was accompanied by different circumstances which decided on the policy's priorities and goals, and were conclusive regarding the choice of instruments. What is more, organizational and financial possibilities that Polish diplomacy had at its disposal were not insignificant. Yet another decisive factor was the conviction about the efficiency of instruments used and the probability of reaching the goal. ${ }^{11}$ When deciding on the use of given instruments, both the resources available to a state, the probable success rate and the costs to be incurred are always considered.

At present, Poland's policy towards the Balkan states is carried out on two parallel tracks, which widens the range of instruments that can influence post-Yugoslav states. Poland implements bilateral contacts of political, economic, cultural and scientific nature with each of the states separately. As agreed in bilateral contracts, Poland uses available instruments of political, economic, military, social and normative nature. At the same time, it takes part in various multilateral initiatives, including EU activities. Instruments used by Polish diplomacy correspond to the

10 R. Zięba, Cele polityki zagranicznej państwa, [in:] Wstęp do teorii polityki zagranicznej państwa, R. Zięba (eds.), Toruń 2004, pp. 37-58.

11 R. Zięba, Paradoksy polityki zagranicznej Polski w okresie transformacji, [in:] Paradoksy polityki, M. Karwat (ed.), Warszawa 2007, pp. 395-397. 
activities performed by EU institutions. Membership in the EU lets Poland realize goals regarding the Balkan states not only on the basis of bilateral contracts, but also on the basis of EU policy. Moreover, a forum of Polish presence in the region are the international organizations involved therein - UN, NATO, OSCE and various sub-regional organizations..$^{12}$ Poland is obliged by its membership status to play an active part in their activities, and instruments applied by those organizations are determined by their character, available resources and goals they pursue.

\section{POLITICAL INSTRUMENTS OF POLISH FOREIGN POLICY TOWARDS FORMER YUGOSLAV STATES}

Among all the foreign policy instruments the crucial role is played by political instruments. These are mostly political contacts with state officials and all types of activities coming under the wide term of diplomatic relations. Thanks to them, opinions can be exchanged, standpoints discussed and coordinated, differences disclosed, pressure exerted, persuasion used, gains offered, compromises reached, joint actions agreed on, decisions to undertake mutual liabilities (treaties) taken, their content negotiated, bilateral contacts extended and stances towards third parties agreed on. ${ }^{13}$ Any activity towards another state, in form of political or diplomatic contacts, can become an action of a positive or negative nature. It is the method adopted by a state that decides about that. Regardless of how political instruments are used, their goal is to achieve particular goals set by the state's foreign policy. These goals can derive from the state's own interest regarding the international community or express the interest of the community itself.

When scrutinizing Poland's activity towards the Balkan states and defining the instruments that were used to shape international relations and influence the situation in the region, one has to consider the factors

12 R. Zięba, Rola ugrupowań subregionalnych w nowym systemie bezpieczeństwa europejskiego, „Studia Europejskie” 2000, No. 1, pp. 27-51.

13 R. Kuźniar, Współczesne..., p. 127. 
which determined the decisions of Polish diplomacy. For Poland, because of its strategic priorities which were connected to the provision of security, intensification and institutionalization of bilateral co-operation, the strengthening of relations with the country's neighbors, the Balkan issue was important only when it threatened, directly or indirectly, the realization of the above goals. This marginalizing of the Balkan issue in Polish policy and subduing to the policy suggested by other states is apparent when you consider Poland's standpoint during the military conflicts in the Balkans. Polish policy towards the Balkan region was not autonomous. Poland was not a creator or initiator of actions pursued by the international community, but merely joined in the actions taken by international organizations and states which located their political and economic interests in that area. Polish diplomacy abstained from ultimate decisions until a final position was formed by the European Community and the USA. Decisions were taken only when forced by circumstances or when a further deferment would have led to some unfavorable consequences. The diplomacy limited its actions to presenting their stance regarding the Balkan events in forms of diplomatic notes, announcements, declarations and objections. The standing of Polish government was reflected in foreign policy documents. Opinions were hinted at also on the public forum, during international and interstate meetings.

Their content was determined by the foreign policy assumptions towards the Balkan region. Unequivocal declarations were not made until the international community had taken a stand. ${ }^{14}$ A good example of that are the circumstances of acknowledging the independence of individual Yugoslav republics and establishing diplomatic relations with them. Polish response to the announcement of declarations of independence by Balkan republics was rather subdued. Initially, we opted for the unity of SFRY reasoning that there were no legal-international grounds to the claiming of independence. Such standpoint was articulated by Polish Ministry of Foreign Affairs in June 1991 in form of a statement. ${ }^{15}$

\footnotetext{
14 See: A. Orzelska, Polska polityka zagraniczna wobec rozbieżności w stosunkach transatlantyckich na tle konfliktów w byłej Jugosławii, „Studia Polityczne” 2009, No. 24, pp. 213-253.

15 Ibidem, p. 222-224.
} 
The successive statement discarded the use of power to solve internal conflicts and declared the readiness to participate in the mediation mission of CSCE if such was to be formed. ${ }^{16}$ Poland approached the newly gained independence with some reservations, though did not undermine explicitly the republics' right to autonomy, concluding however that the acknowledgment of their independence should be the effect of a joint European act. ${ }^{17}$ For a few months Poland did not reach any decision regarding the independence of Slovenia and Croatia making its final content conditional on the position of other European states. Poland acknowledged these republics only when other EC states had recognized their independence.

In the later stages of Yugoslavia's disintegration, Poland also accepted the policy led by international organizations toward the so-called New Yugoslavia (Federal Republic of Yugoslavia - FRY), built on the debris of the old SFRY. In the initial stage of the crisis, Poland tried to pursue a dialogue with all Yugoslav republics, including the Serbian Republic. However, the introduction of political sanctions by EC and UN forced Poland to apply similar restrictions. Polish ambassador was called back from the FRY and subsequently, all political contacts ceased altogether. ${ }^{18}$

Similar premises shaped Polish policy towards the other Yugoslav republics. Polish diplomacy consistently conditioned its stance towards other republics aspiring to independence, that is Bosnia and Herzegovina and Macedonia on the decisions taken by EC and the US. Poland acknowledged their independence shortly after such a statement was announced by EC and the US.

16 M. Habowski, Polityka Polski wobec rozpadu Jugosławii (1991-1995), [in:] Polityka Polski wobec organizacji i państw europejskich 1990-2002, M.S. Wolański (ed.), Wrocław 2003, p. 158.

17 Such opinions were articulated by Krzysztof Skubiszewski, the Minister of Foreign Affairs of the time.

18 In July 1992, Jerzy Chmielewski, Polish ambassador to Belgrade, was summoned back to Poland. Officially, he performed his functions till 31 May 1995. On the other hand, Yugoslavian ambassador Murat Agović left Poland in July 1993. 
First Bosnia and Herzegovina statehood was accepted ${ }^{19}$, then Macedonia's. The delay was caused by the controversy stirred up about the state's proper name. Eventually, when the EU member states accepted Macedonia under the name of Former Yugoslav Republic of Macedonia (FYROM) in December 1993, Poland established diplomatic contacts with the newly formed republic. ${ }^{20}$

The list of Poland's diplomatic actions on the international forum aimed at putting an end to the conflicts and stabilizing the Balkan region was not very long. The instruments applied were predominantly the instruments chosen by international organizations and reflected Poland's membership obligations. Poland was focused on activities in other regions and seldom did it put forward its own initiatives, and if that was the case, they were rather of a marginal character and passed without much notice. ${ }^{21}$ A good example of that was the mission to the US and UN opting for the termination of war in Bosnia and Herzegovina, undertaken in December 1992 jointly with Austria, Hungary, Slovenia and the Czech Republic as part of the Central European Initiative. ${ }^{22}$ Similarly, there were no peace proposals originating from the Polish diplomacy. Poland's activity was restricted to the supporting of peace initiatives formulated by international organizations (e.g. support for the Cyrus Vance and David Owen's peace plan). It supported Taduesz Mazowiecki's mission as the special rapporteur of the UN Human Rights Commission, yet it was limited rather to a support of moral and not diplomatic nature. ${ }^{23}$ Poland also did not have any influence on the course, character and final decisions taken in Dayton.

19 Poland recognized Bosnia and Herzegovina by the resolution of the Council of Ministers of 30 April 1992. Diplomatic relations were established on 22 December 1995.

20 In the EU member states, there was no unanimity on this matter and Greece was the main opponent. The conclusion of the Macedonian- Greek agreement in September 1995 partially solved the problems. Although it did not terminate the dispute regarding the country's name, it enabled the USA to establish full diplomatic contacts with Macedonia and its accession to international organizations.

21 A. Orzelska, Polska..., p. 218.

22 J. Gajewski, Regionalizm w polityce bezpieczeństwa Polski 1989-2000, [in:] Polska polityka bezpieczeństwa 1989-2000, R. Kuźniar (ed.), Warszawa 2001, p. 264.

23 A. Orzelska, Polska..., p. 231. 
Although a Polish delegation co-signed the agreement of 14 December 1995 in Paris and also participated in London conference dedicated to the civil aspects of the treaty's implementation, in fact it played only a marginal role which went unnoticed even by Polish public opinion.

The activity of Polish diplomacy did not change its character in the years succeeding the conclusion of the peace treaty. Poland participated actively in actions supporting the reinforcement of peace and stability in the post-Yugoslav region, but these were multilateral actions and Poland was not an initiator of any of them. What was noteworthy was the duties implied by Poland being the leader of the $\mathrm{OSCE}^{24}$, as well as the role played by HeNo.yk Sokalski as the head of the UN diplomatic mission on the territory of Macedonia. ${ }^{25}$ Another remarkable fact was Marek Antoni Nowicki's position as the International Human Rights Ombudsman in Kosovo in the years 2000-2005, and from January 2008 as the head of the Advisory Commission on Human Rights in Kosovo.

The analysis of the scope of bilateral relations with post-Yugoslav states and description of instruments used to shape bilateral relations must be performed in the context of events unfolding in the Balkans and successive stages of Yugoslavia's dissolution. In the initial stage of its dissolution, the standpoint towards actions undertaken by individual republics was manifested through the establishment of diplomatic relations, diplomatic posts and summoning of ambassadors back to Poland for a consultation. Polish diplomacy stance was reflected in the intensity of political contacts and the level at which bilateral talks were held. The regularity of meetings held by experts and other consultations of a political nature and, most of all, settlements that were eventually made proved the stance and intentions of Polish diplomacy. The quality of contacts is also reflected in the fact that it was a high level political dialogue, held with vice-ministers, ministers, prime ministers and presidents. The disapproval of actions taken by the Balkan states was manifested in the postponement of the minister

\footnotetext{
24 See: O działaniach polskiego przewodnictwa OBWE na rzecz rozwiązania kryzysu w Kosowie, „Biuletyn MSZ” 1998, No. 20; O rezultatach i doświadczeniach polskiego przewodnictwa OBWE w 1998 roku, „Biuletyn MSZ” 1999, No. 1.

25 See: H. Sokalski, Odrobina prewencji. Dorobek dyplomacji prewencyjnej ONZ w Macedonii, Warszawa 2007.
} 
of foreign affair's visits or in the rejection of invitations to a political dialogue made by a Balkan state.

Instruments used by Polish diplomacy corresponded to the priorities set in foreign policy and the financial and organizational possibilities that were available at the time. Equally important was the policy led by the Balkan states and methods of the policy implementation in the region. Moreover, the decisions taken by the international community obliging Poland to apply particular measures were not insignificant. Depending on the role played by political instruments shaping bilateral contacts with a given state of the Balkan conflict, these included contacts between politicians at parliamentary, governmental or presidential level. Bilateral talks were also held during multilateral meetings and conferences. Their purpose was to intensify political relations, negotiate standpoints, clarify differences, seek compromises and negotiate the content of international agreements. The instruments applied were those which worked most efficiently towards the accomplishment of goals set in bilateral relations. The use of diplomatic measures was aimed to reinforce bilateral relations or, if need arose, manifest the attitude towards actions taken by the other party. The intensity of Poland's political contact with states that came into being on the rubble of the former Yugoslavia depended on a number of factors. A significant factor was the progress of political transformation process, the extent to which the Dayton peace treaty regulations were being observed and the policy carried out in the region. Poland was interested in reviving the co-operation with Balkan republics and the symptoms of stability in the region encouraged Polish diplomacy to intensify their efforts. Poland offered to share its experience and provide help with the transformation of the political system in such areas as: denationalization, reforms of public finance, economic consulting, building a citizen society and structures of local democracy. ${ }^{26}$

Poland supported all actions by the Balkan states during transition which were Europe-oriented and aimed at reinforcement of democracy.

\footnotetext{
26 Pismo ministra spraw zagranicznych Włodzimierza Cimoszewicza do Jarosława Kalinowskiego wiceprezesa Rady Ministrów, 30 listopad 2001, Archiwum KPRM, Sekretariat Prezesa Rady Ministrów Jerzego Buzka, Leszka Millera, Zagraniczne wyjazdy służbowe członków rządu, prezesa KPRM, przyjazdy delegacji zagranicznych, 511/42.
} 
It is well reflected in international agreements signed with those states and proved by the support given to their efforts to gain membership in, inter alia, the Council of Europe, Central European Free Trade Agreement (CEFTA), Central European Initiative or later on in EU and NATO. However, it was not an unconditional support. It was treated as an instrument of exercising influence on the policy of those states. In case they did not keep the international obligations accepted by them, Polish diplomacy abstained from supporting their actions on the international forum.

\section{MILITARY INSTRUMENTS OF POLISH FOREIGN POLICY}

Among military measures we can distinguish measures, the use of which is a proof of a failure or inefficiency of other means of foreign policy, such as interventions and operations intended to scare, pressurize, demonstrate power or an armament race. In contacts with allied states or at least friendly states which carry out a dialogue, it is possible to use military means of a different nature, such as support in the supply of armaments, training, consulting or passing of strategic information. ${ }^{27}$

Implementing its foreign policy towards the Balkan region, Poland used various military instruments. Their purpose was to accomplish particular goals regarding this region and to support the achievement of strategic priorities set by Polish foreign policy. Poland's involvement in the operations led by international organizations in the Balkans should be examined in this context. Poland, building an image of a country which does not avoid responsibility, was striving to enhance its chances to accomplish strategic goals regarding its foreign policy and security, which at the time were tantamount to membership in Euro-Atlantic structures. Participation in peace missions was an instrument supporting the realization of Poland's priorities and proved its commitment to peace, security and international stabilization. ${ }^{28}$

27 R. Kuźniar, Międzynarodowe..., p. 128.

28 See: Polityka bezpieczeństwa i strategia obronna RP, „Przegląd Rządowy” 1992, No. 12; Strategia bezpieczeństwa narodowego Rzeczypospolitej Polskiej, „Przegląd Rządowy” 2000, No. 1; Strategia bezpieczeństwa narodowego Rzeczypospolitej Polskiej, 
From the very beginning Poland was involved in actions led by international organizations to reestablish and sustain peace and security in the Balkans. ${ }^{29}$ It joined in operations of all international organizations engaged in sustaining stability in the region, both led by UN (UNPROFOR, UNCRO, UNPSG, UNTAES, UNPREDEP, UNMPOP, UNMIBH) and NATO (IFOR, SFOR, AFOR, KFOR), OSCE and the European Union (e.g. EUFOR ALTHEA). ${ }^{30}$ The participation of Polish soldiers, policemen, border army force and firemen in various missions and operations became a characteristic feature of Polish foreign policy and is its significant instrument to date ${ }^{31}$. Poland, joining in operations led by NATO, even before it was given access to its structures, tried to build an image of a state which has the means to engage in peace and security enforcement operations in the world. ${ }^{32}$

International missions and operations carried on the territory of the Balkan states was just one of the ways by which the international community influenced the parties to the conflict. In the initial stage of the crisis, faced with no response to the appeals for a cease-fire, first the European Community and soon after that the UN Security Council imposed economic sanctions on FRY. These included an embargo on supply of arms and military equipment. ${ }^{33}$ After the support for Bosnian Serbs was stopped in 1994 and the peace treaty in Dayton signed in December

http://www.msz.gov.pl/Strategia,Bezpieczenstwa,Narodowego,RP,162.html; Strategia bezpieczeństwa narodowego Rzeczypospolitej Polskiej, http://www.bbn.gov.pl/portal.php? serwis $=$ pl\&dzial $=475 \&$ id $=1144 \&$ search $=698$.

29 C. Marcinkowski, Operacje pokojowe na początku XXI wieku, Warszawa 2004, pp. 48, 56-63.

30 J. Dobrowolska-Polak, Międzynarodowa solidarność. Operacje pokojowe ONZ, NATO $i$ UE, „IZ Policy Papers”, No. 3.

31 See: C. Kącki, Siły wielonarodowe do misji pokojowych, Warszawa 2003; http://www. unic.un.org.pl/misje_pokojowe/pl_mzeu.php; Polacy w służbie pokoju 1953-2003, Warszawa 2002; H. Sokalski, Odrobina prewencji, Białystok 2007; E. Posel-Częścik, Wspótpraca NATO i Unii Europejskiej $w$ dziedzinie opanowywania kryzysów, „Biuletyn” PISM 2004, No. 39, p. 2.

32 B. Górka-Winter, Udział Polski w operacjach pokojowych i stabilizacyjnych, „Rocznik polskiej polityki zagranicznej 2007”, p. 275.

33 United Nations Security Council Resolution No. 713 of 25 September. 
1995, a gradual lifting (or temporary suspension) of UN sanctions took place, including embargo on supply of arms and military equipment. Nonetheless, Poland obligated itself to observe the embargo. In the context of its aspirations to EU and unwilling to break out of the joint position of EU and associated states, each time the peace terms or international standards were violated by FRY, Poland agreed with the stance taken by the EU. ${ }^{34}$ In another act of solidarity, in the time to come, Poland joined in successive sanctions, including embargoes on supply of arms, munitions and equipment imposed by the UN SC. ${ }^{35}$

The continuation of the repressive policy of FRY towards Kosovian Albanians triggered UN's more pungent reaction. Failure of diplomatic talks led to a decision to launch air raids on Serbian military and strategic targets in spring 1999. Although Poland did not take part in these UN actions, it did support it as an instrument of pressurizing Serbian government. Approval of the peace plan and succeeding political transformations in FRY induced the international community, including Poland, to remove the restrictions gradually.

In its aspiration to tighten bilateral relations with the Balkan states, Polish diplomacy extended the scope of this collaboration, from political to military. The latter took the form of consultations, sharing of experience and trainings. It was assumed that this support was not only to intensify mutual relations, but also to bind them closer to the Euro-Atlantic region. Post-Yugoslav states were interested in this co-operation, too. Such interest was voiced by Croatia, which welcomed the co-operation of defense industries (once the embargo was lifted), as well as training of Croatian officers in Polish military academies and drawing on Polish experience in

34 See: Rada Ministrów podjęła uchwale w sprawie przyłaczenia się Rzeczypospolitej Polskiej do Deklaracji Państw Członkowskich Unii Europejskiej z 26 lutego 1996 r. w sprawie utrzymania zakazu dostaw broni, amunicji i wyposażenia wojskowego na tereny byłej Jugosławii, http://www.poprzedniastrona.premier.gov.pl/archiwum/1937_3384.htm; Common Position of 19 March 1998 defined by the Council on the basis of Article J.2 of the Treaty on European Union on restrictive measures against the Federal Republic of Yugoslavia (98/240/CFSP), Dz.U. L 58, 7.03.1996.

${ }_{35}$ Komunikat po Radzie Ministrów, 7 IV 1998, http://www.poprzedniastrona.premier. gov.pl/archiwum/1937_3130.htm 
the implementation of "Partnership for Peace" programme. ${ }^{36}$ Poland was also interested in establishing military relations with Slovenia through expanding the accreditation scope of military attachés. Poland opted for academic and technical co-operation and other projects within the framework of peace operations. ${ }^{37}$ Later on, it actively supported the efforts of the Balkan states to join UN, offering its guidance and assistance.

\section{ECONOMIC INSTRUMENTS OF POLISH FOREIGN POLICY}

Economic instruments comprise a state's resources and the ways in which they are used. The scope and character of economic instruments, the way they are used and effects they bring about for a state's foreign policy, including the possibility to influence international community, depend on existent economic potential and the advancement of industry, trade and finances. ${ }^{38} \mathrm{~A}$ state striving to accomplish its foreign policy goals uses economic instruments to enhance its chances to realize political objectives. By using particular instruments a state can influence another state's position, attitude or actions and persuade it to embark on ventures that are desired. Available instruments can be used in two ways corresponding to the application of negative or positive methods. Negative methods include complete or partial ban on economic exchange, refusal of credits, various forms of discrimination in the trade circulation or launching an economic blockade. ${ }^{39}$ Positive methods include, inter alia, special considerations given in commercial exchange, investments, credit granting, consulting, training and other forms of support coming under

36 Sprawozdanie z wizyty delegacji Ministerstwa Obrony Narodowej RP pod przewodnictwem ministra obrony narodowej Piotra Kołodziejczyka $w$ Republice Chorwacji, 18-19 września 1994 r., Archiwum KPRM, Urząd Rady Ministrów, Gabinet Prezesa Rady Ministrów Waldemara Pawlaka, 2781/33.

37 Sprawozdanie z wizyty oficjalnej Ministra Obrony Republiki Słowenii Pana Jelko Kacina w Polsce, Archiwum KPRM, Urząd Rady Ministrów, Gabinet Prezesa Rady Ministrów Józefa Oleksego, Włodzimierza Pawlaka, Sprawozdania z wyjazdów, T. I, 3045/24/2.

38 J. Kukułka, Międzynarodowe stosunki polityczne, Warszawa 1984, p. 45.

39 R. Kuźniar, Międzynarodowe..., p. 127. 
the wide term of economic aid (developmental, humanitarian, technical aid) ${ }^{40}$ All these actions can contribute to the process of political transformation, boost economic growth and encourage a policy acceptable to the international community.

Economic instruments used by Poland and directed at the Balkan states had various forms. Those applied before the conflict came to an end and the peace treaty was signed, were different from the ones used later on. Poland's access to the EU also played a significant role, as due to that the range of available instruments became much wider. Nonetheless, regardless of the newly gained EU membership, due to Poland's financial condition, those instruments were still limited. Regardless of the available resources and potential, the government believed that Poland's economic aid would contribute to the stability and security in the region, reinforce the process of political transformation and would tighten the links between the region and the EU. ${ }^{41}$

Depending on how the political situation was developing in given postYugoslav states and on the policy they led, economic instruments were used in a negative or positive way. Inefficiency of diplomatic endeavors and escalation of the conflict prompted the international community's decision to impose economic sanctions on the FRY government. ${ }^{42}$ Poland followed the footsteps of UN and EC resolution and introduced economic sanctions. ${ }^{43}$ In the coming years, as the states started to conform to peace

40 J. Zając, Środki..., p. 21.

41 Odpowiedź ministra spraw zagranicznych - z upoważnienia prezesa Rady Ministrów - na interpelację No. 5536 w sprawie normalizacji stosunków polskojugosłowiańskich, http://orka2.sejm.gov.pl/IZ3.nsf.

42 Notatka informacyjna w sprawie zniesienia sankcji Rady Bezpieczeństwa w stosunku do państw byłej Jugosławii, Archiwum KPRM, Urząd Rady Ministrów, Gabinet Prezesa Rady Ministrów Józefa. Oleksego, Włodzimierza Cimoszewicza, Przyjazdy delegacji zagranicznych, T. VIII, 3045/25/9.

43 Rozporządzenie Rady Ministrów z dnia 22 czerwca 1992 r. w sprawie zakazu obrotu towarowego z Federalna Republika Jugosławii (Serbia i Czarnogóra), DzU, 1992, No. 54, entry 255; Uchwała No. 54 Rady Ministrów z dnia 24 czerwca 1993 r. w sprawie wykonania postanowień rezolucji No. 820 Rady Bezpieczeństwa Organizacji Narodów Zjednoczonych z 18 kwietnia 1993 r. dotyczacych środków podjętych wobec władz Federalnej Republiki Jugosławii (Serbii i Czarnogóry), MP, No. 33, poz. 336. 
obligations, the sanctions were gradually alleviated or in some exceptional cases, tightened (e.g. in response to repression imposed by Serbian authorities in Kosovo).

Poland's endeavors to reinforce peace, democracy, human rights observance and to improve the economic situation and attain stability in the region by using economic instruments ran on two parallel tracks. One part was connected to the actions of the international community, whilst the other was realized independently, in form of contracts and economic or trade agreements, non-returnable financial aid or low-interest rate loans. These measures were aimed at reinforcing political dialogue and, on the other hand, supporting the Balkan states in the process of system transformation. A good example of Poland joining in the new strategy adopted by the international community in the Balkans was its interest in membership in the Stability Pact for the South-Eastern Europe adopted in 1999 in Cologne. The access criteria precluded Poland for quite a time from becoming the Pact's member. Poland strove hard to acquire a membership status, yet it was not successful in its attempts and until its accession to the EU, it held the status of an observer. This status enabled it to participate in a number of projects and discussions, yet the influence on documents' content and decision-taking was very limited. However, this does not mean that Poland did not participate in the Pact's activities. It did, through its active participation in numerous projects and working sessions. ${ }^{44}$

Poland's support for the transformations occurring in the Balkans was also manifested through the projects realized within the framework of Regional Partnership. ${ }^{45}$ In October 2005 in Budapest, during a meeting of

44 See: E. Cziomer, Pakt Stabilności dla Europy Południowo-Wschodniej, [in:] Ogniska konfliktów..., p. 18-22; B. Górka-Winter, Polityka zewnętrzna UE wobec Bałkanów Zachodnich - wniosek Chorwacji o przystapienie do UE, „Biuletyn”, PISM 2003, No. 36, p. 2; J. Tombiński, Udział Polski w realizacji programu Paktu Stabilności dla Europy PołudniowoWschodniej, [in:] Ogniska konfliktów..., p. 12; M. Nawrot, Udział Polski w Pakcie Stabilności dla Europy Południowo-Wschodniej, „Rocznik polskiej polityki zagranicznej 2001”, Warszawa 2001, p. 155.

45 The Regional Partnership, which came to life in 2001 upon Austria's initiative, was a form of cooperation and consulting comprising of, apart for the initiating state, Czech, Poland, Slovakia, Slovenia and Hungary. 
foreign affairs ministers representing the Regional Partnership member states and the Western Balkans, Hungary put forward an initiative to offer EU pre-accession aid to the Balkan states. The member states of the Regional Partnership committed themselves to provide aid, each in a specific area. Poland was appointed the coordinator of the area regarding the use of EU assistance funds. ${ }^{46}$

Under this bilateral cooperation, Poland provided the assistance of experts in the economic transformation process so that the denationalization experience could be shared and drawn on. Our proposals corresponded to the pace at which changes were occurring in particular states. The list of economic instruments was diversified. It depended to an equal degree on the progress of the political stabilization process and the resources available. Poland offered trainings and expert consultations. What is more, Poland also participated in the project for renewal and reconstruction areas damaged by war. The Council of Ministers resolved to grant a non-returnable loan to the government of Bosnia and Herzegovina in the amount of 3 million USD. ${ }^{47}$ Similar aid was provided in 1998. The funds were allocated to the purchase goods and services in Poland. ${ }^{48}$

What is more, the Balkan states were offered preferential loans. A loan in the amount of 50 million was granted to Yugoslavia. A relevant agreement was concluded on 16 October 2002 and put into force on 3 December that year. ${ }^{49}$ The loan was allocated to finance the supply of machinery, equipment and energy and mining services to the Federal Republic of

46 Informacja na temat działań Polski w związku z inicjatywą Partnerstwa Regionalnego na rzecz wspierania procesu integracji państw regionu Bałkanów Zachodnich z Unia Europejska, http://www.ukie.gov.pl/www/dpr.nsf/main?open.

47 Komunikat po Radzie Ministrów, 28.05.1996, http://www.poprzedniastrona.premier.gov.pl/archiwum/1937_3366.htm.

48 Komunikat po Radzie Ministrów, 3.07.1998, http://www.poprzedniastrona.premier. gov.pl/archiwum/1937_3083.htm.

49 See: Umowa między Rządem Rzeczypospolitej Polskiej a Federalnym Rządem Federalnej Republiki Jugosławii o udzieleniu kredytu, Archiwum KPRM, Sekretariat Prezesa Rady Ministrów, File 3861-4141; MP, 2003, No. 21, entry 320; http://www.mofnet.gov. $\mathrm{pl} /$ dokument.php? const $=1 \& \mathrm{dzial}=153 \& \mathrm{id}=5405 \&$ PortalMF $=\mathrm{c} 037 \mathrm{f} 8 \mathrm{fc}$. 
Yugoslavia. ${ }^{50}$ In 2008 a preferential loan was granted to Montenegro and dedicated to the modernization of railway infrastructure and agriculture (agreement of April 2006). ${ }^{51}$

Humanitarian aid was yet another instrument of Polish foreign policy towards the Balkan states. It was provided from the very beginning of Yugoslavian crisis and lasted also at the time when economic sanctions were enforced. Humanitarian aid consisted of organizing food and medical convoys, setting up field hospitals and helping civilians in any way possible during military actions and also during the peace enforcement period. Poland gave shelter to refugees, admitted the injured into Polish medical centers and provided aid to children and youth.

Although at the moment the Balkan states are not on the priority list for Poland's aid programs, still support is provided under bilateral aid agreements. Polish assistance in this region focuses on European integration, support of political transformation in its broad meaning and the development of territorial self-government. ${ }^{52}$ In 2010 the state's budget allocated 100 million PLN for external assistance programs implemented through the Ministry of Foreign Affairs. These aid funds will be divided between Albania, Bosnia and Herzegovina, Montenegro, Macedonia and Serbia and Kosovo. ${ }^{53}$

50 See: Umowa między Rządem Rzeczypospolitej Polskiej a Federalnym Rządem Federalnej Republiki Jugosławii o udzieleniu kredytu, Archiwum KPRM. Sekretariat Prezesa Rady Ministrów, File 3861-4141; MP, 2003, No. 21, entry 320; http://www.mofnet.gov. $\mathrm{pl} /$ dokument.php? const $=1 \& \mathrm{dzial}=153 \& \mathrm{id}=5405 \&$ PortalMF $=\mathrm{c} 037 \mathrm{f} 8 \mathrm{fc}$.

51 Współpraca gospodarcza: Czarnogóra, http://www.mg.gov.pl/Wspolpraca+z+ zagranica/Wspolpraca+gospodarcza+Polski+z+krajami+UE+i+EFTA/Wspolpraca+go spodarcza+Czarnogora.htm; Porozumienie z dnia 22 października 2008 r. między Rządem Rzeczypospolitej Polskiej a Rządem Czarnogóry o zmianie Umowy między Rządem Rzeczypospolitej Polskiej a Radą Ministrów Serbii i Czarnogóry o udzieleniu kredytu w ramach pomocy wiązanej, sporządzonej w Warszawie dnia 20 kwietnia 2006 r., MP, 2003, No. 9, entry 94.

52 http://www.polskapomoc.gov.pl/Pozostale,kraje,23.html.

53 Program polskiej pomocy zagranicznej udzielanej za pośrednictwem MSZ RP w roku 2010, http://www.polskapomoc.gov.pl/Dokumenty,i,publikacje,83.html. 


\section{SUMMARY}

Poland's participation in multilateral actions taken by the international community, as well as in initiatives launched under bilateral agreements, was a purposeful attempt of Polish diplomacy to have influence upon the ending of the military conflict and the political and economic situation in the post-Yugoslav region. Poland's declared motivation was the willingness to join in operations to sustain international peace and regional, or even global security. Such arguments as long history of friendly interstate relations, of fruitful political, economic, scientific and cultural relations were brought up. At the same time Poland's involvement was intended to support the accomplishment of strategic goals set by foreign policy, including accession to NATO and EU.

Even if one is careful no to overrate the influence of Polish diplomacy on stabilizing the situation in the region, Poland's commitment is clearly noticeable. Thanks to the presence in the Balkans, Poland has definitely reinforced its image as a reliable and active state and also strengthened its position on the international arena. Poland's involvement in peace operations and missions has become a significant instrument of its foreign policy. However, it is arguable whether Poland used all of its available resources to participate in the solving of the Balkan issue, whether it was objective in its assessment of unfolding events and whether it did not follow other states and international organizations too closely, at the expense of the policy's authenticity. Another question that comes up is whether individual attempts to shape Poland's policy towards the post-Yugoslav states, especially in initial phases of the conflict, were sufficient. 